\title{
LEPTOSPIROSIS - A CASE REPORT
}

\author{
Alexandru Predescu2 , Sorina Diaconu ${ }^{1,2}$, Nicoleta Tiuca ${ }^{1,2}$, Adina Purcareanu ${ }^{1,2}$, Alina Tomescu², \\ Denisa Cuciureanu², Filip Petruta ${ }^{2}$, Palan Ana Maria², Calota Carmen², Corina Pop ${ }^{1,2}$ \\ ${ }^{1 " C a r o l ~ D a v i l a " ~ U n i v e r s i t y ~ o f ~ M e d i c i n e ~ a n d ~ P h a r m a c y, ~ B u c h a r e s t ~}$ \\ ${ }^{2}$ Internal Medicine II and Gastroenterology Clinic, Emergency University Hospital, Bucharest \\ Corresponding author: \\ Alexandru Predescu
}

Address: 169 Splaiul Independentei Street, Sector 5, Bucharest, Romania

E-mail: predescu_alexandru25@yahoo.ro

\begin{abstract}
Leptospirosis is a spirochaetal zoonosis, with a broad spectrum of clinical manifestations, ranging from mild (febrile illness) to fulminant forms (systemic disease with jaundice and kidney failure - Weil's disease).

We present the case of a 62 year old patient, with no personal pathological incidents, brought to the emergency room for fever, chills, myalgia, nausea, vomiting, abdominal pain, for 14 days, with jaundice, shortness of breath, and confusion for 72 hours. Clinical examination revealed fever, confusion, jaundice, tachypnoea, tachycardia, irregular heart rhythm, hypotension, anuria, hepatomegaly, no clinical signs of liver cirrhosis or flapping tremor. Laboratory tests revealed leucocytosis with neutrophilia, hepatic cytolysis, renal failure, rhabdomyolysis, while the imagistic investigations were normal. Serological tests were performed for viral, drug induced hepatitis, autoimmune diseases, other infectious diseases (Elisa and ultramicroscopic agglutination tests were positive for leptospirosis). Later, the patient's condition worsened, resulting in intubation and mechanical ventilation, persistence of febrile syndrome and jaundice, bilateral lower limb petechiae with hepatic encephalopathy. Broad spectrum antibiotics (Ceftriaxone and Penicillin G), dialysis, hydroelectrolytic rebalancing, Dopamine support, antiarrhythmic drugs were administered, and the hepatic encephalopathy was also treated. The outcome was favourable (extubation, resolution of febrile syndrome, inflammation, jaundice and hepatic encephalopathy).

This case is an example of atypical, monophasic leptospirosis which is common in Weil's disease (the most severe form of leptospirosis), with onset as a febrile illness leading to multiple system organ failure.
\end{abstract}

Keywords: Leptospirosis, Weil's disease, Elisa, jaundice. 


\section{INTE}

\section{Rezumat}

Leptospiroza este o zoonoză spirochetală cu spectru larg de manifestări clinice, de la forme ușoare (boală febrilă), la forme fulminante (boală sistemică cu sindrom icteric și insuficiență renală - sindromul Weil).

Prezentăm cazul unui pacient de 62 de ani, fără APP semnificative, adus la camera de gardă pentru febră, frisoane, mialgii, greață, vărsături, dureri abdominale, debutate de 14 zile, însoțite de icter sclero-tegumentar, dispnee de repaus și confuzie de 72 ore. Obiectiv am observat un pacient febril, confuz, icteric, tahipneic, tahicardic, ritm neregulat, hipotensiv, anuric, hepatomegalie, fără semne clinice de ciroză și fără flapping tremor. Paraclinic s-a evidențiat leucocitoză cu neutrofilie, citoliză hepatică, retenție azotată și rabdomioliză, investigațiile imagistice fiind normale. S-au efectuat teste serologice pentru hepatite virale, toxic-medicamentoase, boli autoimune, alte boli infecțioase (test Elisa și aglutinare ultramicroscopică fiind pozitive pentru Leptospiroză). Ulterior starea pacientului se agravează, fiind intubat și ventilat mecanic, persistă sindromul febril și sindromul icteric, apar peteșii maleolare și gambiere bilaterale cu encefalopatie hepatică. Se inițiază antibioterapie (Ceftriaxonă și Penicilina G), dializă, reechilibrare hidroelectrolitică, suport dopaminergic, antiaritmic, se tratează encefalopatia hepatică. Evoluția a fost favorabilă (detubare, remiterea sindromului febril, inflamator, icteric și encefalopatiei hepatice).

Acest caz de leptospiroză atipică, monofazică, întâlnit în cadrul sindromului Weil (cea mai gravă formă de leptospiroză), putând debuta ca o boală febrilă cu evoluție către insuficiență multiplă de organe.

Cuvinte cheie: leptospiroză, sindromul Weil, Elisa, icter. 
We present the case of a 62 year old male, with no personal pathological incidents or family medical history, smoker (25 PA), occasional alcohol consumer, presenting to the emergency room of the Bucharest Emergency University Hospital with fever (38 Celsius degrees), chills, myalgia, nausea, vomiting, diffuse abdominal pain, with onset of symptoms in the past 10-14 days, with jaundice, shortness of breath, confusion for 72 hours.

The clinical examination on admittance revealed a confused patient with jaundice, tachypnoea (respiratory rate: 30 breaths/ minute), pulmonary: bilateral breath sounds, bilateral basal crepitant rales, Sp $02=90 \%$ in exhaled air and while resting, cardiovascular: $B P=60 / 40 \mathrm{mmHg}, A V=150 \mathrm{BPM}$, irregular rhythm, unequal and weak heart sounds, without clinically detectable murmur, hepatomegaly (liver with rounded edges, painless on palpation), anuria, no cutaneous manifestations of liver cirrhosis or flapping tremor. After the clinical examination and case history the following stage diagnosis was established: probable septic shock, jaundice syndrome under etiological observation.

Laboratory tests performed in the ER revealed: leucocytosis with neutrophilia $(17350 / \mathrm{mm} 3, \mathrm{Neu}=89.7 \%)$, moderate thrombocytopaenia (58000/mm3), significant inflammatory syndrome (fibrinogen: 1083 $\mathrm{mg} / \mathrm{dL}, \mathrm{CRP}>30 \mathrm{mg} / \mathrm{dL}$ ), nitrogen retention syndrome (creatinine: $6.59 \mathrm{mg} / \mathrm{dL}$, urea: 303 $\mathrm{mg} / \mathrm{dL}$ ), hepatic cytolysis syndrome (ALT: 388 $\mathrm{U} / \mathrm{L}, \mathrm{AST}$ : $530 \mathrm{U} / \mathrm{L}$ ), hyperbilirubinemia with predominating direct bilirubin (BT: 15.53 $\mathrm{mg} / \mathrm{dL}$, BD: $13.33 \mathrm{mg} / \mathrm{dL}$ ), rhabdomyolysis (CK: 1574 U/L, CK-MB: 144 U/L), NT-proBNP $>30000 \mathrm{pg} / \mathrm{mL}$, presepsin: $1340 \mathrm{pg} / \mathrm{mL}$. Also hepatitis viral marker samples were taken for hepatitis B, C (Ag HBs - negative, Ac anti-HCV - negative), urinalysis revealed proteinuria (300 mg/dL) and microscopic haematuria (200 mg/dL), and the acid-base levels showed a moderate metabolic acidosis.

An EKG showed an atrial fibrillation with $A V=$ 155 BPM, with no terminal ischemic changes; chest X-ray revealed an enlarged heart, without any progressive pleural-pulmonary lesions and the abdominal X-ray showed no hydroaeric levels and no pneumoperitoneum. The abdominal ultrasound revealed a non lithiasic gallbladder, no fluid in the peritoneal cavity, while the echocardiography revealed a $40-45 \%$ LVEF, no significant valvulopathy, diastolic dysfunction caused by a delayed relaxation. An abdominal - pelvic native CT scan is performed - no tomodensitometric alterations.

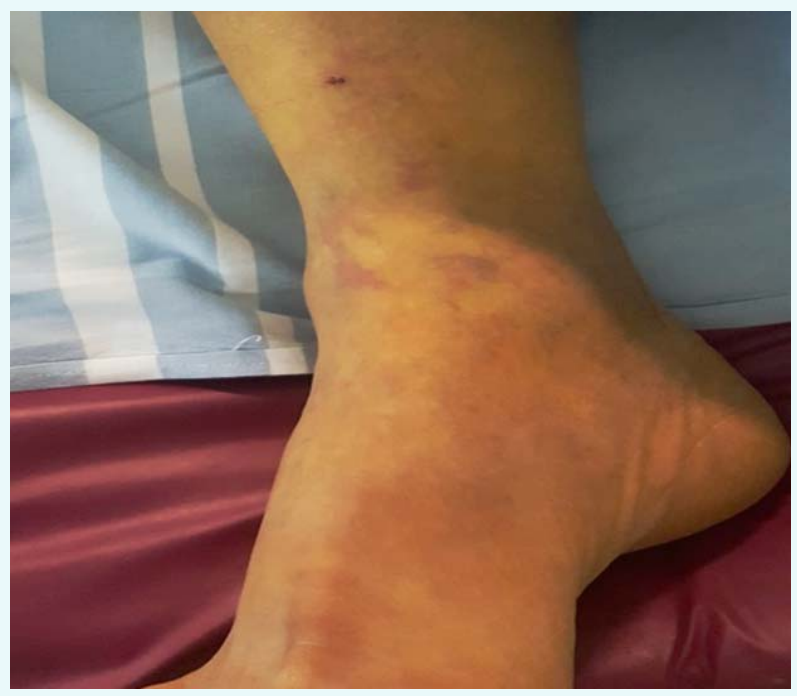

Figure 1. Bilateral lower limb petechiae

The initial clinical evolution is not favourable, with aggravated dyspnoea, the patient being orotracheally intubated and mechanically ventilated, with persisting fever (38.5-39 degrees Celsius), jaundice, bilateral lower limb petechiae (figure 1), cardiovascular: BP $=100 / 60 \mathrm{mmHg}$ with Dopamine support, AV $=110$ BPM, irregular heartbeat, no heart murmur, developing hepatic encephalopathy 
and it is decided that the patient be transferred to the intensive care unit.

The differential diagnosis revealed the following: liver cirrhosis with hepatorenal syndrome, acute viral hepatitis, drug induced hepatitis (acetaminophen, isoniazid, tetracycline, MDMA, toxins: Amanita Philloides, Bacillus Cereus), neoplasms (pancreatic cancer, ampullary carcinoma, cholangiocarcinoma), cholangitis, other infectious diseases (leptospirosis), autoimmune diseases (Wilson's Disease, autoimmune hepatitis), septic shock.

The evolution of the biological parameters was favourable (table 1 ) with regressing I e ucocytosis $(10.500 / \mathrm{mm} 3)$, thrombocytopenia $(90.000 / \mathrm{mm} 3)$, inflammatory syndrome (256 mg/dL), nitrogen retention syndrome (creatinine: 1.2 $\mathrm{mg} / \mathrm{dL}$ ), hepatic cytolysis syndrome (ALT: 60 $\mathrm{U} / \mathrm{L}, \mathrm{AST}: 98 \mathrm{U} / \mathrm{L}), \mathrm{BT}: 4.66 \mathrm{mg} / \mathrm{dL}$, rhabdomyolysis (CK: 270 U/L, CK-MB: 34 U/L). Also, serological markers were taken for acute hepatis (anti VHA, anti VHE antibodies negative); for other hepatotropic viruses (anti CMV IgM antibodies, anti EBV IgM antibodies, anti HSV IgM antibodies, anti-HIV antibodies negative); initial rapid agglutination test for leptospirosis - negative (afterwards serology samples were sent to the Infectious Diseases National Institute Prof. Dr. Matei Bals where specific tests were performed: ultramicroscopic agglutination and ELISA test for leptospirosis with positive results); ceruloplasmin, urine copper - within normal levels, funduscopic examination - no KayserFleischer rings; ANA antibodies, anti-smooth muscle, anti LKM1 - negative and a lumbar puncture was performed - no pathological elements.

Three days after admission a chest and lung X-ray was taken (figure 2) - it revealed 2/3 inferior bilateral alveolar infiltrates, followed by repeating the chest-abdomen-pelvic CT: alveolar filling areas with an air bronchogram in the Fowler segment region and upper left lobe, cardiomegaly, mild ascites in the peritoneal cavity.

Therapeutic approach - initially, treatment with hydroelectrolytic rebalancing solutions was initiated, Dopamine support, dialysis, empirical antibiotic therapy with Meropenem $1 \mathrm{~g}$ every 6 hours, Vancomycin $1 \mathrm{~g}$ every 12 hours, Penicillin G 3 mil $U$ every 4 hours, antiarrhythmic (Amiodarone $2 \mathrm{~mL} /$ hour via syringe pump), PPIs; after serology confirmed Leptospirosis specific antibiotic therapy was initiated with Ceftriaxone $1 \mathrm{~g}$ every 12 hours and Penicillin G 3 mil $U$ every 4 hours, fresh frozen plasma, vitamin K, Normix, Lactulose and a liver transplant was considered. The evolution under therapy was favourable (extubation, progressive resolution of symptomatology: resolution of the febrile syndrome, of inflammation and jaundice and of the hepatic encephalopathy). 


\begin{tabular}{|c|c|c|c|c|c|c|}
\hline & $\mathbf{0 1 . 1 1}$ & $\mathbf{0 2 . 1 1}$ & $\mathbf{0 3 . 1 1}$ & $\mathbf{0 6 . 1 1}$ & $\mathbf{0 7 . 1 1}$ & $\mathbf{0 9 . 1 1}$ \\
\hline WBC & 29.4 & 42.6 & 27 & 24.1 & 21.3 & 10.5 \\
\hline HGB & 10.3 & 10.1 & 8.9 & 6.3 & 9.5 & 10.6 \\
\hline PLT & 63 & 13 & 7 & 17 & 46 & 90 \\
\hline Fibrinogen & 669 & 742 & 348 & 276 & 317 & 256 \\
\hline Creat & 7.25 & 3.86 & 1.86 & 1.4 & 1.3 & 1.2 \\
\hline ALT & 388 & 996 & 380 & 61 & 81 & 60 \\
\hline AST & 506 & 2442 & 520 & 112 & 104 & 98 \\
\hline BT & 16.88 & 24.38 & 38.91 & 18.2 & 10.3 & 4.66 \\
\hline CK & 1369 & 631 & 531 & 263 & 258 & 270 \\
\hline CKMB & 103 & 65 & 42 & 34 & 46 & 34 \\
\hline
\end{tabular}

Table 1 Paraclinical evolution of laboratory examinations: favourable with resolution of the hepatic cytolysis syndrome, nitrogen retention syndrome, rhabdomyolysis, thrombocytopenia and hyperbilirubinemia

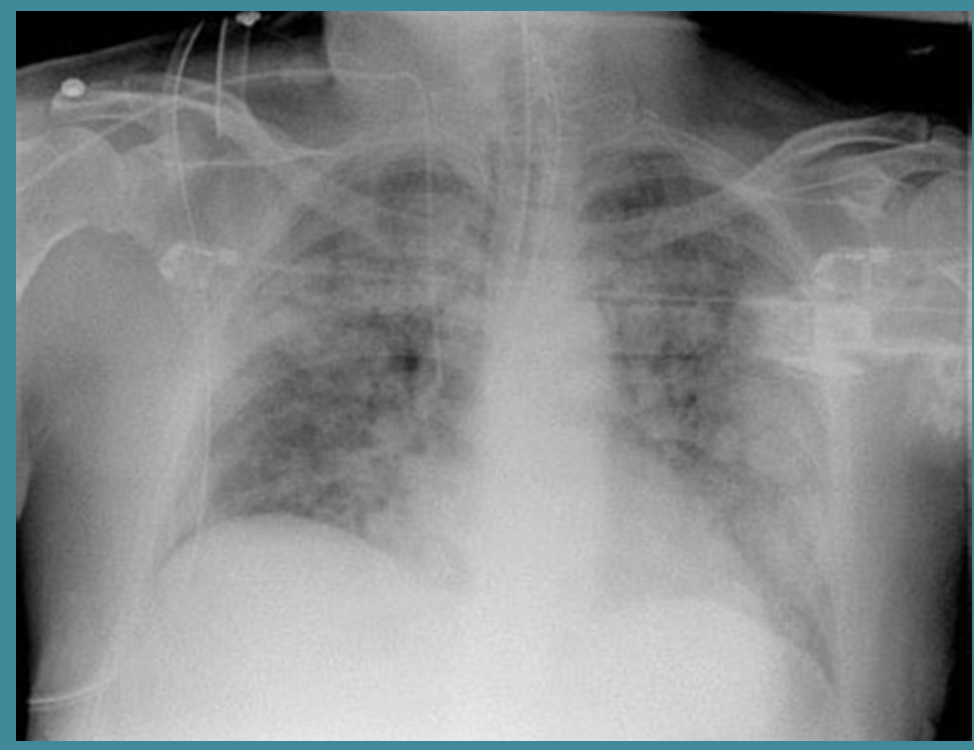

Figure 2. 2/3 inferior bilateral alveolar infiltrates 


\section{Discussions}

Leptospirosis is an infectious disease determined by pathogen Leptospira, with a broad spectrum of clinical manifestations, ranging from mild to fulminant, fatal forms. Presently 21 species are known with over 200 serovariants (traditionally 2 species: L. Interrogans and L. Biflexa)(1).) They are spiralled, thin organisms, with great mobility, hook-like ends and 2 flagella that allow the microorganisms to penetrate the tissue. They are 6-20 $\mu \mathrm{m}$ long and $0.1 \mu \mathrm{m}$ wide $^{(2)}$. These aspects can be noticed with dark field microscopy and after silver staining (figures 3 and 4).

Epidemiologically, it is a zoonosis with wide distribution and the following hosts: rats (most important), dogs, other wild mammals, fish and birds. Transmission can occur directly through urine, blood and infected animal tissue; indirectly through contaminated water and soil; interhuman: rarely. It often appears in the Tropics because of the climate with frequent floods, precarious hygiene and work conditions. The following professional groups are at a high risk: veterinarians, farmers, sewer workers, slaughter house workers, the fishing industry ${ }^{(2,3,4,5,6)}$.

The main entrance points are skin abrasions, exposed mucosa (conjunctival, nasal, oral), consumption of contaminated water ${ }^{(2,3,4,5,6)}$. Etiopathogenic mechanism - the spirochetes penetrate the organism through the aforementioned points, they produce leptospiraemia with hematogenous spread, damaging the capillary endothelium and consecutive vasculitis. The vasculitis produces kidney damage (interstitial nephritis and tubular necrosis that cause hypovolemia and kidney failure); liver damage (centrilobular necrosis, Kuppfer cell proliferation/ severe hepatic cell necrosis with jaundice development); lung damage (pulmonary bleeding)(7). The mechanisms of action are insufficiently known, a few suppositions have been established regarding the binding of spirochaetal endotoxins with the toll-like 4 receptors to produce haemolytic toxins and tissue damage; an immune mediated mechanism through the HLA DQ6 gene with Tlymphocytes activation; certain surface lipoproteins (LipL32) produce interstitial nephritis ${ }^{(1)}$.

Leptospirosis has an incubation period of 714 days that can vary between 2-26 days, and the evolution of the disease includes 2 phases: a septicaemic phase (acute with headaches, myalgia, fever $>39$ degrees Celsius, recurrent chills, conjunctival suffusion on day 3-4, hepatosplenomegaly rarely) that lasts 4-9 days; an immune phase (on day 6-12 of the disease, antibodies appear in the serum; rarely the following complications can occur: aseptic meningitis, 


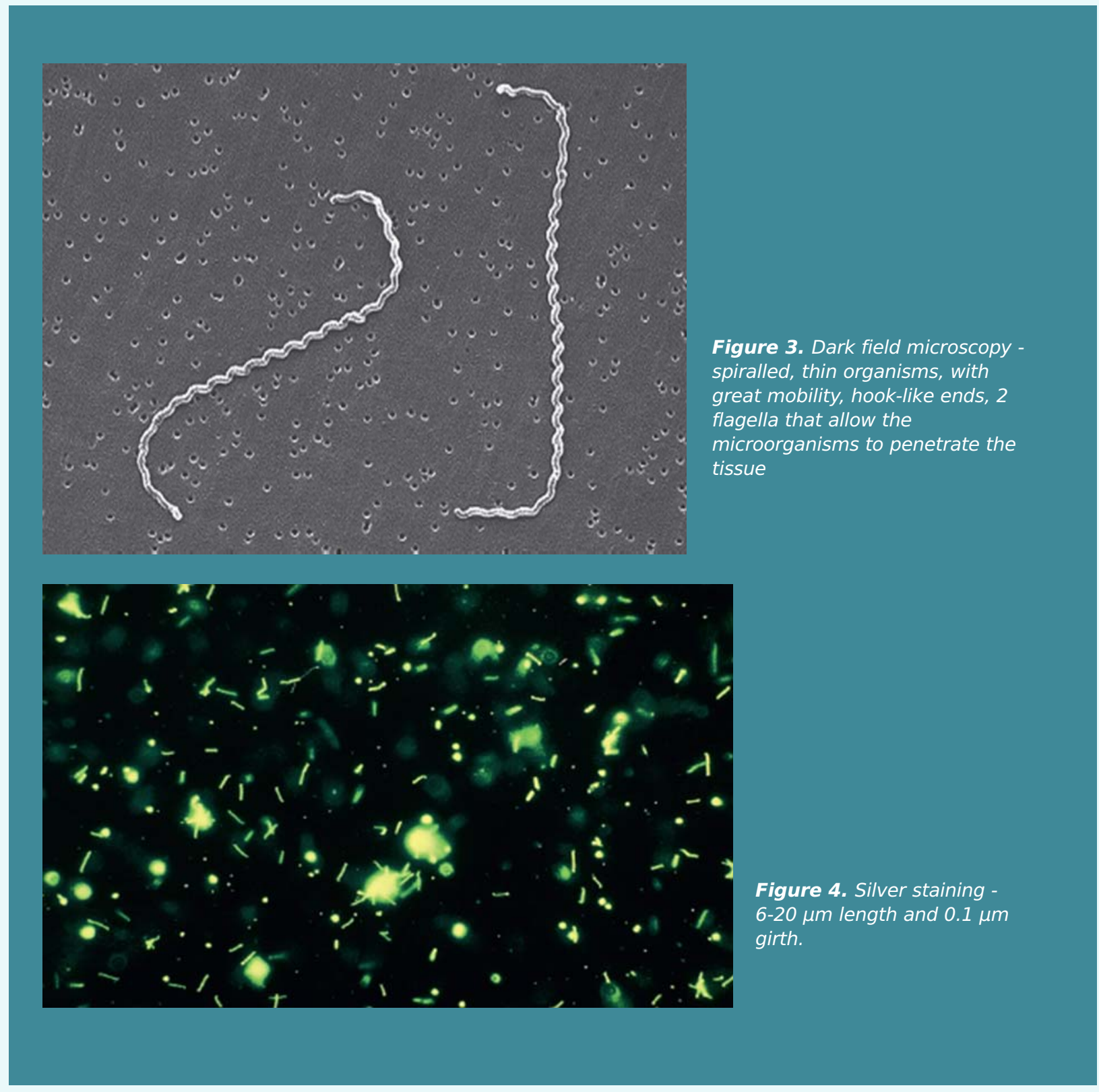

optic neuritis, peripheral neuropathy, iridocyclitis). In case of a pregnancy, this pathology can cause spontaneous abortions. It presents under two clinical forms. Anicteric leptospirosis includes $90 \%$ of cases, being an acute disease similar to the flu (fever, chills, intense frontal or retroorbital headaches, nausea, vomiting, myalgias of the calf, lumbar, abdominal myalgia; rarely, rash, dysphagia, hepatosplenomegaly, mental confusion can occur). Patients can become asymptomatic after 7-14 days, or sometimes weeks later. In the immune phase they can develop aseptic meningitis ${ }^{(8,9)}$. Icteric leptospirosis (Weil syndrome) includes 5-10\% of cases, it is a severe form with a high mortality rate, with jaundice after 4-9 days; renal dysfunction (oliguria/anuria); bleeding diatheses (epistaxis, petechia, purpura, ecchymosis), frequent hepatosplenomegaly; lung damage (coughing, dyspnoea, haemoptysis, respiratory failure, severe pulmonary haemorrhagic syndrome); rarely, gastrointestinal, adrenal, subarachnoid haemorrhaging; rhabdomyolysis, myocarditis, pericarditis, congestive heart 


\section{INTERNAL}

\section{Clinical cases}

failure, cardiogenic shock, respiratory distress, multiple organ failure; being an example of a monophasic disease $\mathrm{e}^{(10,11,12,13,14,15)}$. The positive diagnosis is made with the ELISA test with positive anti IgM antibodies for Leptospira and with CRP (Leptospira DNA confirms the diagnosis in the early stage). Other non-specific tests are: microscopic agglutination test (MAT), macroscopic agglutination test, urinalysis tests (rarely used, two hours after collection of sample), CSF (presence of proteins, normal/low glucose, PMN predominance $)^{(16,17,18)}$. The differential diagnosis is made with malaria, enteric fever, viral hepatitis, Hantavirus infections, rickets, Dengue fever, Legionella $^{(19,20,21)}$.

Treatment options in the anicteric form include Doxycycline $100 \mathrm{mg} /$ day per os, Ampicillin 500-750 mg every 6 hours per os, Amoxicillin $500 \mathrm{mg}$ every 6 hours per os and, for the icteric form, Penicillin G 1.5 mil U every 6 hours iv, Ceftriaxone $1 \mathrm{~g}$ every 12 hours iv, Ampicillin 500 mg - $1 \mathrm{~g}$ every 6 hours iv. These treatment plans will be administered for 7-10 days according to the guidelines. ${ }^{(1)}$.

The prognosis varies based on the form of the disease. In the anicteric form we have a low mortality rate; in the icteric one a $5-10 \%$ and in the severe pulmonary haemorrhagic syndrome it can go up to $50 \%$. Among the factors that can favour a negative outcome we recall age over 60 , acute renal failure (oliguria/anuria, hyperkalaemia, serum creatinine $>3 \mathrm{mg} / \mathrm{dL}$ ) acute respiratory failure (dyspnoea, pulmonary rales, haemoptysis), hypotension, arrythmia, mental confusion ${ }^{(22,23,24)}$.

The main leptospirosis prevention methods are: avoiding endemic risk zones, avoiding direct contact with potentially infected animals, avoiding indirect contact with contaminated soils and waters, wearing protective gear (boots, rubber gloves, glasses), immunising domestic animals, prophylactic Doxycycline $200 \mathrm{mg} /$ week $^{(25,26,27,28) \text {. }}$

\section{Conclusions}

The presented case is an example of acute leptospirosis that did not evolve in a biphasic manner, but manifested as a monophasic, fulminant form, that can be fatal. Weil syndrome is one of the most severe forms of leptospirosis, rarely encountered, that can be a possible cause for prolonged febrile syndrome which can develop complication such as multiple organ failure; with an important clinical and epidemiological significance, this pathology can be fatal. Early diagnosis and emergency initiation of empirical antibiotic therapy are important $^{(23,24,28)}$.

Conflict of interest: non-existent 


\section{References:}

1. John E. Bennett, Raphael Dolin, Martin J. Blaser; Mandell, Douglas and Bennett's Principles and Practice of Infectious Diseases; Eighth Edition; Volume 1; Elsevier Sauders; 2014; 241: 2714-2720

2. Joseph M. Vinetz et al; Sporadic Urban Leptospirosis; Annals of Internal Medicine; 199615 Nov; 125(10): 794798; DOI: 10.7326/0003-4819-125-10-199611150-00002

3. Bharti A.R., Nally J.E., Vinetz J.M.; Leptospirosis: a zoonotic disease of global importance; Lancet Infectious Disease 2003; 3:757-71

4. Levett P.N.; Leptospirosis; Clin Microbiol Rev 2001;14:296-326.

5. Figueiredo L.T.M., Morelli M.L., Sousa R.L.M.; Emerging Infectious Diseases; 2003;9(7):892-3.

6. Megan A. Stobart Gallagher; Noel Dunn; Leptospirosis (Weils Disease); NCBI; 2017 Oct 6; Bookshelf ID: NBK441858

7. Saito $M, Y$ A M Villanueva $S$, Masuzawa $T$, Yanagihara $Y$, Yoshida S; Leptospirosis now-the centennial of the discovery of Weil's disease pathogen; Nippon Saikingaku Zasshi. 2014;69(4):589-600.

8. David A. Haake; Human Leptospirosis Clinical Management; International Leptospirosis Society; www.leptosociety.org; 2004; 1-20

9. Michael Camilleri, J. Gregory Fitz, Anthony N. Kalloo, Fergus Shanahan, Timothy C. Wang; Yamada's Textbook of Gastroenterology; Sixth Edition, Volume 2;2016; 98: 1973

10. Spichler $A$ et al; Weil's disease: an unusually fulminant presentation characterized by pulmonary haemorrhage and shock; Braz Journal of Infectious Diseases; 2005 Aug 9; (4): 336-340. Epub 2005 Nov 1.

11. Pothuri $P$ et al; Leptospirosis Presenting with Rapidly Progressing Acute Renal Failure and Conjugated Hyperbilirubinemia: A case Report; Am J Case Report; 2016 Aug 10; 17: 567-569

12. Pushpakuma J et al; Myocarditis causing severe heart failure- an unusual early manifestation of leptospirosis: a case report; BMC Res Notes; 2015 Mar 13; 8:80. Doi: 10.1186/s13104-015-1031-1

13. Elias Maroun et al; Fulminant Leptospirosis (Weil's disease) in an urban setting as un overlooked cause of multiorgan failure: a case report; J Med Case Reports; 2011 Jan 14; Doi: 10.1186/1752-1947-5-7

14. Agrawal VK, Bansal A, Pujani M; A rare case of leptospirosis with isolated lung involvement; Indian J Crit Care Med. 2015 Mar;19(3):174-6.

15. Balakrishnan T, Moore A, Krishnamoorthy S, Davies G, Ka Ho Lee $P$; Weil's disease presenting as atypical pneumonia; Acute Med. 2014;13(4):178-81.

16. Chakrabarti A, Nandy M, Pal D, Mallik S; A rare case of
Weil's disease with alveolar haemorrhage; Asian PacJ Trop Biomed. 2014 May;4(Suppl 1):S66-9.

17. Shintaku M, Itoh H, Tsutsumi Y; Weil's disease (leptospirosis) manifesting as fulminant hepatic failure: report of an autopsy case; Pathol. Res. Pract. 2014 Dec;210(12):1134-7.

18. Edilane L. Gouveia et al; Leptospirosis associated Severe Pulmonary Haemorrhagic Syndrome, Salvador, Brazil; NCBI; 2008 Mar; 14(3): 505508; doi: 10.3201/eid1403.071064

19. Segura ER, Ganoza CA, Campos K, RicaldiJN, Torres S, Silva $H$, et al; Clinical spectrum of pulmonary involvement in leptospirosis in a region of endemicity, with quantification of leptospiral burden; Clin Infect Dis 2005;40:34351 10.1086/427110

20. Marotto PC, Nascimento CM, Eluf-Neto J, Marotto MS, Andrade L, Sztajnbok J, et al; Acute lung injury in leptospirosis: clinical and laboratory features, outcome, and factors associated with mortality; Clin Infect Dis 1999;29:15613 10.1086/313501

21. Nicodemo AC, Duarte MI, Alves VA, Takakura CF, Santos RT, Nicodemo EL; Lung lesions in human leptospirosis: microscopic, immunohistochemical, and ultrastructural features related to thrombocytopenia; $\mathrm{Am} J$ Trop Med Hyg 1997; 56:1817

22. Centers for disease Control and Prevention, National Center for Emerging and Zoonotic Infectious Diseases, Division of High-Consequence Pathogens and Pathology; Leptospirosis; https://www.cdc.gov/leptospirosis/; 2015; $1-20$

23. Jensen PM, De Fine Licht $\mathrm{HH}$; Predicting global variation in infectious disease severity: A bottom-up approach; Evol Med Public Health. 2016 Feb 15;2016(1):85-94.

24. Panaphut T, Domrongkitchaiporn S, Thinkamrop B; Prognostic factors of death in leptospirosis: a prospective cohort study in Khon Kaen, Thailand; Int J Infect Dis 2002;6:529 10.1016/S1201-9712(02)90137-2

25. T.J. Coleman; World Health Organization, International Leptospirosis Society; Human Leptospirosis Guidance for diagnosis, surveillance and control; www.who/int/en; 2003; 17-31

26. National Institute of Communicable Diseases, World Health Organization; Guidelines for prevention and control of Leptospirosis; www.who/int/en; 2006; 3-21

27. Song AT, Abas L, Andrade LC, Andraus $W$, $D$ 'Albuquerque $L A$, Abdala E; A first report of leptospirosis after liver transplantation; Transpl Infect Dis. 2016 Feb;18(1):137-40

28. Kathryn Senior; Leptospirosis and Weils syndrome: Cause for concern?; The Lancet Infectious Diseases; 2010 Dec; Doi: https://doi.org/10.1016/S1473-3099(10)70268-1 